\title{
A COMPARATIVE PERFORMANCE ANALYSIS OF A 1 MW CIS PV SYSTEM AND A 5 KW CRYSTALLINE-SI PV SYSTEM UNDER THE TROPICAL CLIMATE OF INDONESIA
}

\author{
Kun Kunaifi ${ }^{1,2^{*}}$, Angèle Reinders ${ }^{1,3}$, Dimas Kaharudin ${ }^{4}$, Aripriantoni Harmanto ${ }^{4}$, \\ Kirjono Mudiarto ${ }^{4}$ \\ ${ }^{1}$ Department of Design, Production and Management, Faculty of Engineering Technology, \\ University of Twente, Enschede, The Netherlands \\ ${ }^{2}$ UIN Sultan Syarif Kasim Riau University, Pekanbaru, Indonesia \\ ${ }^{3}$ Energy Technology Group, Department of Mechanical Engineering, Eindhoven University of \\ Technology, Eindhoven, The Netherlands \\ ${ }^{4}$ PT. Pembangkitan Jawa-Bali, Jl. Ketintang Baru No. 11 Surabaya, Indonesia
}

(Received: August 2019 / Revised: October 2019 / Accepted: October 2019)

\begin{abstract}
Despite being a tropical country with great potential for solar power, knowledge about the actual performance of photovoltaic (PV) systems in Indonesia remains limited. In this paper, using 5minute resolution data from 2016 to 2018 obtained from a 1 MW Copper Indium Selenide (CIS) and a $5 \mathrm{~kW}$ crystalline silicon (c-Si) PV plant in West Java, we aim to answer the question of how a CIS PV plant performs and degrades in Indonesia's tropical climate and how it compares to a PV system that contains c-Si technology. The methodological approach used includes performance analyses of these PV systems according to IEC standard 61724 and an investigation of the degradation rate using NREL/RdTools. The following results were derived from the analyses: the total annual $H_{i}$ was $1500 \mathrm{kWh} / \mathrm{m}^{2}$ or around $4.2 \mathrm{kWh} / \mathrm{m}^{2} /$ day. The daily-averaged performance ratio, $P R$, was $91.7 \% \pm 4 \%$ and $87.4 \% \pm 7 \%$ for the CIS system with string inverters and a central inverter, respectively. The mean $P R$ of the CIS systems was $12 \%$ higher than that of the c-Si system, which was $79.8 \%$. Concerning the final yield, $Y_{f}$, the CIS system with a mean $Y_{f}$ of $3.85 \mathrm{kWh} / \mathrm{kWp}$ outperformed the c-Si system by $14 \%$. The CIS system degraded by $1.53 \%$ per year, which is less than the c-Si system with a degradation rate $\left(R_{d}\right)$ of $3.72 \%$ per year. From these results, it can be concluded that, in this case, CIS technology performs better than c-Si in Indonesia's tropical climate. Uncertainties in the calculation and high values of $R_{d}$ could be areas for further investigation.
\end{abstract}

Keywords: Degradation; Indonesia; Performance; PV systems; Tropical climate

\section{INTRODUCTION}

Indonesia has many rural areas and remote islands that are suitable for distributed renewable power generation such as solar photovoltaic (PV) systems. PV systems are reliable power systems and play an essential role in climate change mitigation (Creutzig et al., 2017). The market for PV systems is beginning to grow rapidly worldwide owing to, among other factors, their increased efficiency, the increased lifespans of the components, and a rapid reduction in their cost (Fraunhofer ISE, 2019). 
The first PV system applications in Indonesia can be traced back to 1978 and the installation of a 5 $\mathrm{kWp}$ solar water pumping system (Dasuki et al., 2001). Various other projects then followed, such as a solar home systems (SHS) pilot project (Reinders et al., 1999), desalination plants, basic medical applications, remote televisions, and water pumping systems (Veldhuis \& Reinders, 2015). A large SHS demonstration project with a total capacity of $50 \mathrm{MWp}$ was launched in 1994 (Veldhuis \& Reinders, 2015), and the first urban PV system was introduced in 2003 (Ministry of Energy and Mineral Resources, 2012).

Since then, many other PV systems have been constructed and created employment (Elfani, 2011). However, it is only relatively recently that Indonesia has gained experience in the performance of PV systems (Kunaifi \& Reinders, 2018), and it continues to be in the research and demonstration phase (Veldhuis \& Reinders, 2015). To date, Indonesia has 12 utility-scale PV plants in operation, mainly for off-grid or industrial applications. The dominant PV technology applied is typically crystalline silicon (c-Si) technology.

The PV market in Indonesia is emerging and is expected to grow over the coming years across the vast expanse of Indonesia's archipelago. The factors driving its growth include Indonesia's unique geography, comprising six large and more than 17 thousand smaller islands. This type of geographical factor presents a challenge in terms of extending the conventional power grid to reach the whole of the country's population of more than 260 million. The other motivations for solar electrification in Indonesia include, among others, the increasing demand for electricity (around $5.5 \%$ annual growth) and economic growth of $5 \%$ per year.

PV systems are suitable for use on the large islands (urban areas), particularly with respect to increasing the quality of the power supply (Nazir et al., 2016) as Indonesia is characterized by the relatively low reliability of its electricity supply (Kunaifi \& Reinders, 2018). Meanwhile, on the smaller islands and in more remote areas, PV systems could play a significant role in providing electricity to local people who have not had it before, replacing fossil-fuel-generated electricity with renewables, and increasing the electrification ratio (PLN, 2018).

It is essential to monitor the operation of a PV system in order to identify performance trends. Monitoring data is also crucial for the localization of potential faults and to enable a comparison of PV system performance against design expectations and guarantees and between the different configurations and locations (The International Electrotechnical Commission, 2017). However, most PV systems in Indonesia are not monitored, with only a few equipped with basic monitoring systems. Accordingly, we have limited knowledge about the actual performance of PV systems operating under real environmental conditions in Indonesia. The two PV systems presented in this paper are among the few that are monitored.

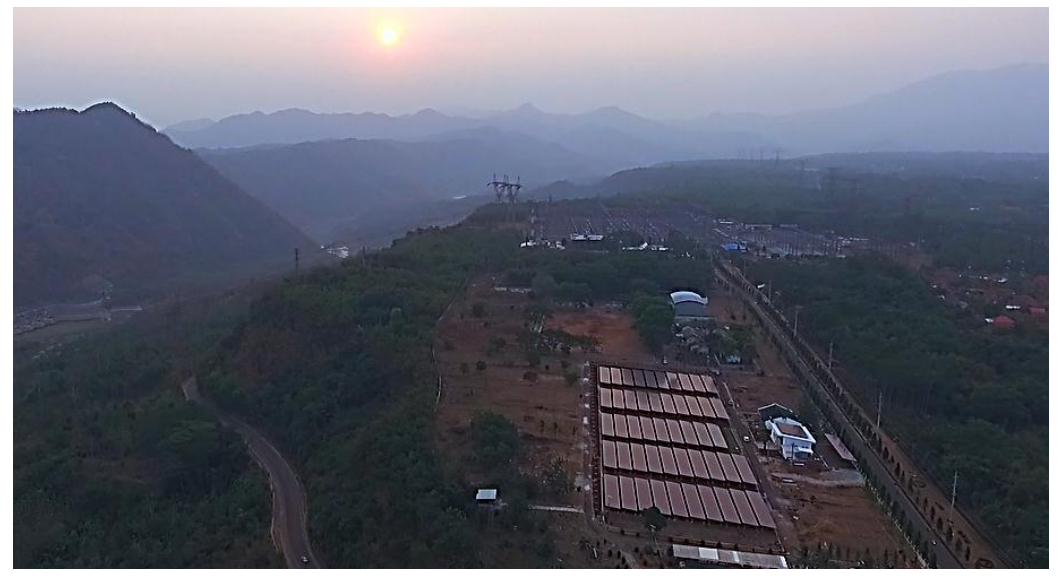

Figure 1 Aerial view of the 1 MW PV plant in Cirata, West Java, Indonesia (Photo: PJB Cirata). 
In September 2015, PT. Pembangkitan Jawa-Bali (PJB), a subsidiary of PLN, Indonesia's stateowned utility company, commenced its entry into the PV business. PJB is a power generation company that operates mainly in Java and Bali, which are the islands with the largest and densest electrical power systems in Indonesia. PJB constructed and now operates and maintains nine power plants with a total capacity of more than $7 \mathrm{GW}$ (PJB, 2019). Among those in operation by PJB is a $1 \mathrm{MW}$ PV system located in the province of West Java, which at the time of its construction was the largest PV system on the island of Java (Figure 1). At the same location, PJB also installed other, smaller PV systems. After three years of operation, we can now, for the first time, analyze the monitoring data from the PV systems in West Java.

In this paper, we therefore seek to answer the following questions:

- How is PJB's 1 MW CIS-based thin-film plant performing, and how has it degraded in Indonesia's tropical climate?

- How do its performance and degradation compare to that of a $5 \mathrm{~kW}$ crystalline (c-Si) plant at the same location?

The motivation for analyzing the performance and degradation of PV systems lies in the fact that the long-term performance and stability of PV plants have a significant impact on the economics of such projects.

Besides performance, degradation is one of the most critical characteristics to consider in the solar PV business. Degradation describes the rate at which a PV module experiences a decline in output. The degradation rate, $R_{d}$, is therefore the rate at which the PV performance of a module decreases per year. $R_{d}$ is an important measure for comparing the actual performance of PV systems against the PV performance warranty issued by the module manufacturer with respect to nominal power.

PV cells degrade (Meyer \& van Dyk, 2004); however, the rate of degradation differs from one PV plant to another. Over the course of a 25 -year operating life, a $20 \%$ decline is considered a failure. Assuming linear degradation, an $R_{d}$ greater than $0.8 \%$ per year can be regarded as a problem (John et al., 2018). For a high-efficiency module, however, $50 \%$ degradation may be acceptable (Jordan \& Kurtz, 2013). Using data from outdoor field testing, the long-term behavior and lifetime of PV modules, including their degradation, can be quantified.

\section{THE PV SYSTEMS AND DATASETS}

The PV systems presented in this paper are located in the Village of Cadas Sari $\left(6^{\circ} 674\right.$ 'S, $\left.107^{\circ} 355^{\prime} \mathrm{E}\right)$, Cirata, the province of West Java. They comprise a $1 \mathrm{MW}$ and a $5 \mathrm{~kW}$ system. The $1 \mathrm{MW}$ plant is ground-mounted over an area of 0.9 ha, while the $5 \mathrm{~kW}$ plant is a rooftop PV installation. Both systems sit in open spaces that are free of shading throughout the year. The measurement equipment is not cleaned and calibrated. Therefore, rather than using the most recent data, we instead use two years of usable data with a starting date close to the system's commencement of operation, based on the assumption that the sensors performed better during their earlier operational period than more recently.

\subsection{MW Thin-Film CIS PV System}

The $1 \mathrm{MW}$ PV plant has $170 \mathrm{Wp}$ Japanese Solar Frontier thin-film PV modules made of Copper Indium Selenide (CIS) technology with a nominal module efficiency, $\eta_{\text {mod }}$, of $13.8 \%$. This efficiency is derived from the module's specification sheet. It has two clusters. One cluster has a capacity of $530.4 \mathrm{~kW}$ and comprises 26 arrays, each with 120 modules. This cluster has an SMA $550 \mathrm{~kW}$ central inverter that delivers AC power to the grid through a transformer. The other cluster, with a total capacity of $510 \mathrm{~kW}$, comprises 25 arrays, each containing 120 modules. Each array is connected to an SMA $20 \mathrm{~kW}$ string inverter. The PV modules are tilted $10^{\circ}$, which is an optimum angle for Indonesia (Setiawan \& Setiawan, 2017), and have an 
azimuth angle of $15^{\circ}$ clockwise from the North.

The monitoring system measured both electrical and meteorological variables at 5-minute intervals over the course of two years between 2016 and 2018. The electrical parameters (inverter-based) include DC current $\left(I_{d c}\right)$ in Amperes, DC voltage $\left(V_{d c}\right)$ in Volts, DC power $\left(P_{d c}\right)$ in Watts, $I_{a c}$ in Amperes, $V_{a c}$ per line in Volts, AC power $\left(P_{a c}\right)$ in Watts, power frequency in Hertz, and cumulative energy production $\left(E_{\text {out }}\right)$ in $\mathrm{kWh}$. There were no data for the months of October 2017 and February 2018. To compensate for these missing data, and in order to ensure two full years' analysis, we used data from 11 March 2016 to 10 May 2018. The total number of daytime records was $95,546,9 \%$ of which were missing or were removed due to outliers, or were wrong, with abnormal values resulting in a monitoring faction $(M F)$ of 0.91 .

As the 1 MW CIS system consists of two separate clusters, we analyzed each cluster individually. For the cluster with a central inverter, we use the term CIS Central (CIS $C$ ), and for the cluster with string inverters, the name CIS String (CIS $)$ is used. The PV module and configuration specifications are shown in Table 1.

Table 1 Specifications of the PV modules in Cirata

\begin{tabular}{lcc}
\hline \multicolumn{1}{c}{ PV Module } & CIS & pc-Si \\
\hline Manufacturer & Solar Frontier, Japan & Victron Energy (cells), \\
Model & SFet (module assembling) \\
$\mathrm{P}_{\max }(\mathrm{Wp})$ & 170 & ASL-M100E \\
$\mathrm{V}_{\text {OC }}(\mathrm{V})$ & 112 & 100 \\
$\mathrm{~V}_{\text {MPP }}(\mathrm{V})$ & 87.5 & 22.3 \\
$\mathrm{I}_{\text {SC }}(\mathrm{A})$ & 2.2 & 18.0 \\
$\mathrm{I}_{\text {MPP }}(\mathrm{A})$ & 1.95 & 6.00 \\
Efficiency $_{\mathrm{T}_{\text {coeff,Pmax }}(\% / \mathrm{K})}$ & 0.138 & 5.60 \\
$\mathrm{~T}_{\text {coeff,Isc }}(\% / \mathrm{K})$ & -0.31 & $\mathrm{NA}$ \\
$\mathrm{T}_{\text {coeff, }}(\% / \mathrm{K})$ & 0.01 & -0.48 \\
NOCT $\left({ }^{\circ} \mathrm{C}\right)$ & -0.30 & 0.037 \\
Length $(\mathrm{mm})$ & 47 & -0.34 \\
Width $(\mathrm{mm})$ & 1,257 & $\mathrm{NA}$ \\
& 977 & 1,000 \\
\hline
\end{tabular}

\subsection{5 kW Crystalline PV System}

The $5 \mathrm{~kW}$ PV plant has $100 \mathrm{Wp}$ poly-crystalline modules that use Victron Energy solar cells assembled into PV modules by an Indonesian company named Azet. It is connected to the local grid through an SMA Sunny Mini Central 5000 inverter. The PV modules are mounted on a building rooftop with a tilt angle of $10^{\circ}$ and an azimuth angle of $15^{\circ}$ clockwise from the North. The monitoring system measures similar parameters to those of the CIS PV system and features the same recording interval of 5 minutes.

For both the CIS and c-Si systems, critical meteorological variables were measured. They include relative humidity $(R H)$ as a percentage, ambient temperature $\left(T_{a}\right)$ in ${ }^{\circ} \mathrm{C}$, module temperature $\left(T_{m}\right)$ in ${ }^{\circ} \mathrm{C}$, global horizontal irradiance $\left(G_{h}\right)$ in Watt $/ \mathrm{m}^{2}$, global in-plane irradiance $\left(G_{i}\right)$ in $\mathrm{Watt} / \mathrm{m}^{2}$, and wind speed $(v)$ at a 1 -metre height in $\mathrm{m} / \mathrm{s}$. Table 2 shows the PV module and configuration specifications. 


\section{METHODS}

All of the monitoring data were checked for consistency and gaps to identify anomalies according to the following method. The daytime data were selected by eliminating irradiance values below $200 \mathrm{~W} / \mathrm{m}^{2}$ and above $1,500 \mathrm{~W} / \mathrm{m}^{2}$. For the ambient temperature, $T_{a}$, only values between -40 and $60^{\circ} \mathrm{C}$ were used. For the module temperature, $T_{m}$, values between the ambient temperature and ambient temperature plus $40{ }^{\circ} \mathrm{C}$ were included. As such, any $T_{m}$ values lower than $T_{a}$ that might occur in the early morning due to irradiation to the sky were excluded from the analysis. For the electrical data, the array voltage between 0 and $1.3 \times V_{o c, s t c}$ was used. Also, the array current values outside 0 and $1.5 \times I_{s c, s t c}$ were excluded from the analysis. Abnormal data, such as large negative values and dead values that stuck for more than one hour, were also removed. Any records missing from the 5-minute data for a period of up to one hour were linearly interpolated.

\subsection{Performance Calculations}

The monitoring standard IEC 61724 was applied to the analysis of the PV systems' performance (The International Electrotechnical Commission, 2017). The performance indicators presented include final yield $\left(Y_{f}\right)$ in $\mathrm{kWh} / \mathrm{kWp}$; array yield $\left(Y_{A}\right)$ in $\mathrm{kWh} / \mathrm{kWp}$; reference yield $\left(Y_{r}\right)$ in $\mathrm{kWh} / \mathrm{kWp}$; capture losses $\left(L_{C}\right)$ in $\mathrm{kWh} / \mathrm{kWp}$; system losses $\left(L_{S}\right)$ in $\mathrm{kWh} / \mathrm{kWp}$; performance ratio $(P R)$ as a percentage or a decimal between 0 and 1 ; efficiencies $(\eta)$ as a percentage or a decimal between 0 and 1; and capacity factor $(C F)$, also given as a percentage.

Yield refers to the ratio of an energy quantity to the array power rating, $P_{\text {rated }}$, of the installed $\mathrm{PV}$ array at standard test conditions (STC) of $1,000 \mathrm{~W} / \mathrm{m}^{2}$ solar irradiance and $25{ }^{\circ} \mathrm{C}$ cell temperature. Thus, yields indicate the actual operation of the array relative to its rated capacity. The unit of yield is $\mathrm{kWh} / \mathrm{kW}$. The ratio of unit is equivalent to hours, and the yield ratio indicates the equivalent amount of time for which the array would be required to operate at $P_{\text {rated }}$ to provide the particular energy quantity measured during the reporting period.

The final yield, $Y_{f}$, is defined as the annual, monthly, or daily net $\mathrm{AC}$ energy output in $\mathrm{kWh}, E_{a c}$, of the PV system per installed rated power, $P_{\text {rated }}$, and is given by Equation 1 . The final yield can be used to compare PV plants with different systems operating in different climates.

$$
Y_{f}=\frac{E_{a c}}{P_{\text {rated }}}\left(\frac{k W h}{k W}\right)
$$

The array yield, $Y_{A}$, is defined as the amount of array energy produced, $E_{d c}$, from each installed rated power, $P_{\text {rated }}$, over the analysis period, as defined by Equation 2 . It is equivalent to the number of hours over which the PV array produces its rated power. The unit of $Y_{A}$ is $\mathrm{kWh} / \mathrm{kWp}$.

$$
Y_{A}=\frac{E_{d c}}{P_{\text {rated }}}\left(\frac{k W h}{k W}\right)
$$

The reference yield in $\mathrm{kWh} / \mathrm{kWp}, Y_{r}$, is the total amount of available in-plane solar irradiance in $\mathrm{kWh} / \mathrm{m}^{2}, H_{i}$, divided by the reference irradiance, $G_{i, r e f}$, of $1,000 \mathrm{~W} / \mathrm{m}^{2}$ (Equation 3).

$$
Y_{r}=\frac{H_{i}}{G_{i, r e f}}\left(\frac{k W h}{k W}\right)
$$

If the reporting period is equal to one day, then $Y_{r}$ would be the equivalent number of sun hours at the reference irradiance per day.

Normalized yield losses are calculated by subtracting yields. The yield losses also have units of $\mathrm{kWh} / \mathrm{kW}$ or hour (h). They represent the amount of time for which the array would be required to operate at its rated power, $P_{\text {rated }}$, to provide for the respective losses during the reporting period. Two types of losses can be calculated once the yields have been determined. These are capture losses, $L_{C}$, and system losses, $L_{S}$. 
$L_{C}$ represents the losses incurred due to the array operating below what would be expected in STC. Losses are typically caused by the effect of temperature, high incidence angles, shading, array circuit losses, including mismatch, low irradiance, and soiling of the array (Pryor et al., 2013). $L_{C}$ is defined by Equation 4.

$$
L_{C}=Y_{r}-Y_{A}\left(\frac{k W h}{k W}\right)
$$

$L_{S}$ represents the losses in the balance of system (BOS) components, including the inverter and all wiring and junction boxes. $L_{S}$ is defined by Equation 5 .

$$
L_{S}=Y_{A}-Y_{f}=\frac{E_{d c}-E_{a c}}{P_{\text {rated }}}\left(\frac{k W h}{k W}\right)
$$

$P R$ is a useful metric that shows how closely a PV system is operating in relation to its ideal rated operation. PR indicates the total losses from the system output due to both array temperature and system component inefficiencies or failures, including the BOS components. The array-level performance ratio, $P R_{A}$, and the system level, $P R$, are defined by Equation 6 and Equation 7. $P R_{A}$ is the ratio of the actual energy produced by the PV array to the available solar energy that can be produced from the PV array at STC efficiency. PR is the ratio of actual energy output to the available solar energy that can be produced from the PV array at STC efficiency. The PR is either unitless or it can be represented as a percentage.

$$
\begin{gathered}
P R_{A}=\frac{Y_{A}}{Y_{r}} \text { (dimensionless) } \\
P R=\frac{Y_{f}}{Y_{r}} \text { (dimensionless) }
\end{gathered}
$$

The efficiency, $\eta$, of a PV system can be calculated as rated array efficiency, $\eta_{A, \text { rated }}$, mean actual array efficiency, $\eta_{A}$, mean system efficiency, $\eta_{f}$, and inverter efficiency, $\eta_{i n v}$, using Equation 8 to Equation 11.

$$
\begin{gathered}
\eta_{A, \text { rated }}=\frac{P_{\text {rated }}}{G_{i, \text { ref }} \times A} \text { (dimensionless) } \\
\eta_{A}=\frac{E_{d c}}{H_{i} \times A} \text { (dimensionless) } \\
\eta_{f}=\frac{E_{a c}}{H_{i} \times A} \text { (dimensionless) } \\
\eta_{i n v}=\frac{E_{a c}}{E_{d c}} \text { (dimensionless) }
\end{gathered}
$$

where $A$ is the effective PV module area in $\mathrm{m}^{2}$.

Finally, $C F$ is defined as the ratio of the actual annual energy output, $E_{a c}$, to the amount of energy the PV system would generate if it operated at full $P_{\text {rated }}$ for $24 \mathrm{~h}$ per day for a year. CF is calculated using Equation 12.

$$
C F=\frac{E_{a c} / A C_{\text {rating }}}{24 x \text { days }} \text { (dimensionless) }
$$

where $A C_{\text {rating, in }} \mathrm{kW}$, is calculated from the sum of the inverter ratings, and the term days is typically 365 or 366 for one year of analysis.

\subsection{Degradation Calculations}

For the $R_{d}$ calculation, NREL/RdTools (Jordan et al., 2018; NREL, 2018) was implemented using Python. RdTools is a set of algorithms for calculating the $R_{d}$ of PV systems based on yearon-year (YOY) analysis using a minimum of two years' time-series data (Jordan et al., 2018). 
RdTools was developed according to the method initially proposed by Hasselbrink et al. (Hasselbrink et al., 2013) based on a review of 3 million module-years of live site data. Using RdTools, PV system production data are evaluated over several years to obtain rates of performance degradation over time. RdTools features an improvement in degradation analysis in that it avoids errors due to irradiance sensor drift, calibration, soiling, or misalignment using the clear-sky method; however, this is outside the scope of this study.

Within RdTools, the computation of the degradation rates from time-series data follows three main steps: normalization, filtering, and data analysis (Jordan et al., 2017). The normalization step involves the calculation of the $P R$ metric normalized by temperature to generate a temperature-corrected $P R$ using Equation 13.

$$
P R=\frac{P}{P_{\text {rated }} * \frac{G_{i}}{G_{i, \text { ref }}} *\left(1+\gamma *\left[T_{\text {cell }}-T_{\text {ref }}\right]\right)} \text { (dimensionless) }
$$

where $P$ is the measured dc power $\left(P_{d c}\right)$ or ac power $\left(P_{a c}\right)$ of the PV system in watts, $\gamma$ is the maximum power temperature coefficient in relative $\% / \mathrm{K}, T_{\text {cell }}$ is the cell temperature in ${ }^{\circ} \mathrm{C}$, and $T_{\text {ref }}$ is the reference temperature in ${ }^{\circ} \mathrm{C}$ with the value of $25^{\circ} \mathrm{C}$ for STC or annual-averaged temperature.

In the filtering step, biasing and nonrepresentative data were removed, as well as data recorded at times when the solar resource was poor or variable. A low irradiance cutoff of $200 \mathrm{~W} / \mathrm{m}^{2}$ was applied in order to exclude start-up irradiance without removing winter data from high-latitude locations. We filtered out data during high de/ac ratio in which power was $>99 \%$ of the maximum value. Finally, data outside of $\mathrm{a} \pm 30 \%$ band around a three-month rolling median performance index were also excluded.

The final step, data analysis, involved the calculation of $R_{d}$ using the remaining data based on three approaches. First, for the YOY method, the rate of change was computed between two points at the same time in subsequent years. This resulted in a histogram of rates of change, the central tendency of which represented the overall system performance. Second, standard least squares (SLS) regression, in contrast, used all data points in a single regression by minimizing the difference between the model and the data. Finally, quantile regression used quantiles instead of the response mean. Prior to analysis of the degradation, the normalized, filtered 15-min data were aggregated over a variable period. Further details on the degradation rate analysis methodology are available in (Hasselbrink et al., 2013) or (Jordan et al., 2017).

\section{RESULTS}

\subsection{System Performances}

The performance analysis covered the evaluation of the solar irradiance on-site and the energy produced by the PV system over time. The mean and maximum daytime values of $G_{i}$ on a surface tilted $10^{\circ}$ during the analysis period were $410 \mathrm{~W} / \mathrm{m}^{2}$ and $1,250 \mathrm{~W} / \mathrm{m}^{2}$, respectively. Figure $2 \mathrm{a}$ shows the $G_{i}$ for the PV array tilted angle in Cirata during the analysis period. As shown, the majority of $G_{i}$ values were in the range from $250 \mathrm{~W} / \mathrm{m}^{2}$ to $800 \mathrm{~W} / \mathrm{m}^{2}$, although a significant frequency of $G_{i}$ below $250 \mathrm{~W} / \mathrm{m}^{2}$ was also observed.

The total annual $H_{i}$ was $1,500 \mathrm{kWh} / \mathrm{m}^{2}$, with the highest value of $143.5 \mathrm{kWh} / \mathrm{m}^{2}$ in August (hot season) and the lowest value of $90.3 \mathrm{kWh} / \mathrm{m}^{2}$ in February (rainy season) (Figure $2 \mathrm{~b}$ ). The monthly average $H_{i}$ was $125 \pm 15 \mathrm{kWh} / \mathrm{m}^{2}$ or around $4.2 \mathrm{kWh} / \mathrm{m}^{2} /$ day. The monthly-averaged $T_{m}$ ranged from $39{ }^{0} \mathrm{C}$ to $43{ }^{0} \mathrm{C}$ (Figure $2 \mathrm{~b}$ ). However, with a data resolution of 5 minutes, $T_{m}$ ranged from $21{ }^{\circ} \mathrm{C}$ to $68{ }^{\circ} \mathrm{C}$.

During the reporting period, the energy amounts supplied to the grid from the CIS and c-Si PV plants were resp. $1,258 \mathrm{MWh}(\approx 3.4 \mathrm{MWh} /$ day $)$ and $6,012 \mathrm{kWh}(\approx 16.5 \mathrm{kWh} /$ day $)$. The average 
daily $Y_{f}$ was $3.66 \mathrm{kWh} / \mathrm{kWp}$ for CISs, $3.84 \mathrm{kWh} / \mathrm{kWp}$ for $\mathrm{CIS}_{\mathrm{C}}$, and $3.31 \mathrm{kWh} / \mathrm{kWp}$ for the c-Si system. In general, the $Y_{f}$ values of the PV systems in Cirata were high, thus demonstrating the significant potential of PV systems in Indonesia (Kunaifi \& Reinders, 2017).

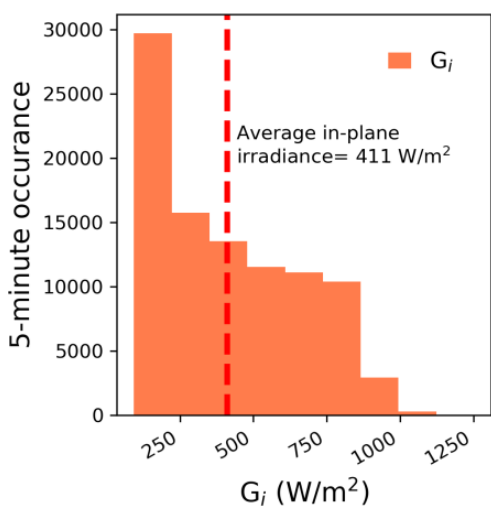

(a)

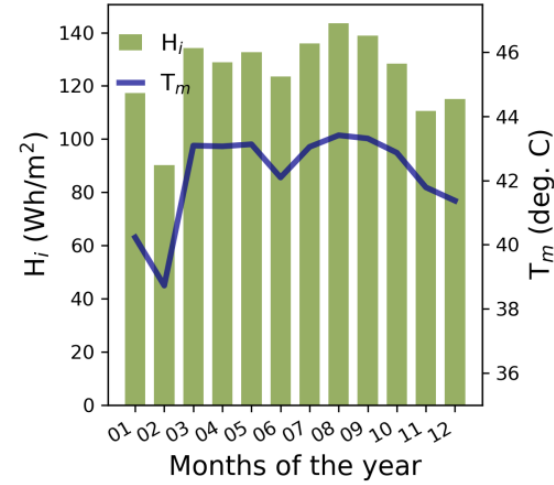

(b)

Figure 2 Meteorological variables in Cirata. (a) Frequency distribution of in-plane irradiance, (b) total monthly irradiation and PV module temperature during daytime hours

Figure 3 shows the $P R$ of the PV systems in Cirata. The daily-averaged $P R$ values for the CIS and CIS $_{C}$ systems during the reporting period were $91.7 \% \pm 4 \%$ and $87.4 \% \pm 7 \%$, respectively. The CIS $\mathrm{C}_{C}$ system has a higher $L_{C}$ and $L_{S}$ than the CIS system, which created a significant difference in $P R$ between the two CIS systems. $P R$ for the c-Si system was $79.8 \% \pm 4 \%$. Table 2 shows the main performance indicators of the three PV systems in Cirata. Using the mean values from CIS $_{\mathrm{C}}$ and $\mathrm{CIS}_{\mathrm{S}}$, it can be seen that the CIS system performed better than the c-Si system. The $Y_{f}$ of CIS was $14.1 \%$ higher than that of the c-Si, which confirms the finding from a recent study (Honrubia-Escribano et al., 2018).

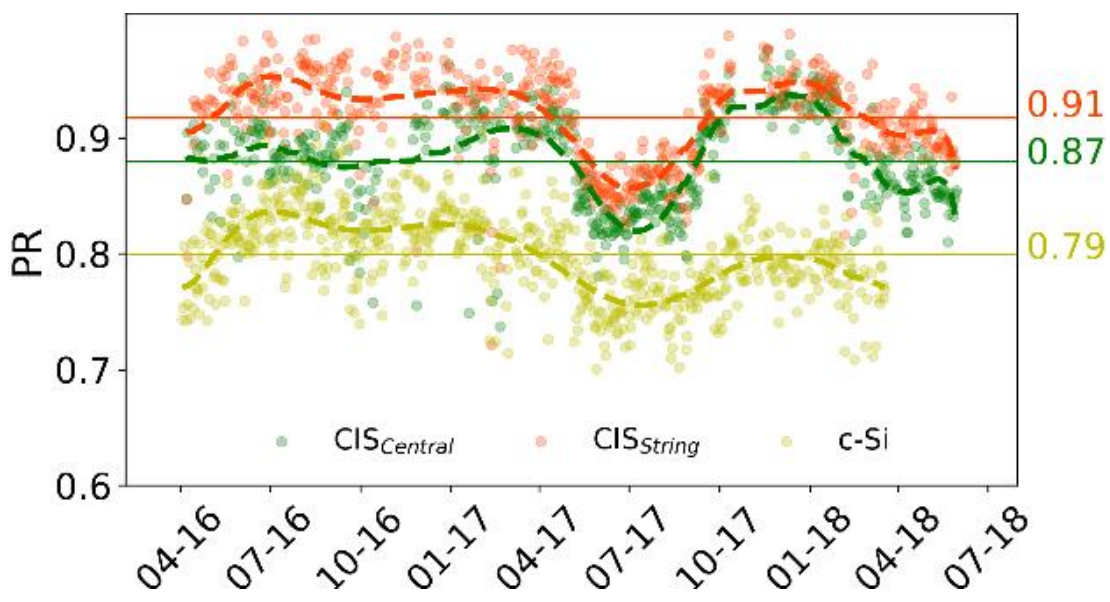

Figure 3 Performance ratios of the PV systems in Cirata; green for $\mathrm{CIS}_{\mathrm{C}}$, orange for $\mathrm{CIS}_{\mathrm{S}}$, and magenta for $\mathrm{c}-\mathrm{Si}$

The most significant difference between the two systems concerns the losses, where the c-Si system yielded a $47 \%$ higher $L_{c}$ and a $45 \%$ higher $L_{s}$ than the CIS. One of the reasons for the lower losses in the CIS systems is the higher frequency of module cleaning compared to the cSi system. The values for $\eta_{A \text {, rated }}$ of the CIS and c-Si system were respectively $13.8 \%$ and 14.9 $\%$. The annual-averaged $C F$ was $16.3 \%$ for $\mathrm{CIS}_{\mathrm{S}}, 16.0 \%$ for $\mathrm{CIS}_{\mathrm{C}}$, and $14.1 \%$ for the c-Si system. 


\subsection{Degradation Rates}

Figure 4 shows the $R_{d}$ of the PV systems in Cirata based on data from April 2016 to July 2018. The degradation rate is a rate of change, with a negative rate representing a decrease in performance. For the CIS system, the calculation is based on the power produced by the central inverter $\left(\mathrm{CIS}_{\mathrm{C}}\right)$. The calculation shows that the c-Si system degraded at an average of $3.72 \%$ per year, which is faster than the CIS system with its annual $R_{d}$ of $1.53 \%$. The values for the confidence interval of the $R_{d}$ of the CIS and c-Si system were $0.87 \%$ to $2.06 \%$ per year and $2.98 \%$ to $4.31 \%$ per year, respectively.

Table 2 Performance indicators of PV systems in Cirata

\begin{tabular}{lccccc}
\hline Indicators & Unit & $\begin{array}{c}510 \mathrm{~kW} \\
\left(\mathrm{CIS}_{\mathrm{S}}\right)\end{array}$ & $\begin{array}{c}532.4 \mathrm{~kW} \\
(\mathrm{CIS})\end{array}$ & $\begin{array}{c}5 \mathrm{~kW} \\
(\mathrm{c}-\mathrm{Si})\end{array}$ & $\begin{array}{c}\mathrm{CIS} / \mathrm{c}-\mathrm{Si} \\
(\%)\end{array}$ \\
\hline$Y_{f}$ & $\mathrm{kWh} / \mathrm{kWp}$ & 3.92 & 3.77 & 3.37 & 14.09 \\
$Y_{A}$ & $\mathrm{kWh} / \mathrm{kWp}$ & 4.00 & 3.91 & 3.58 & 10.47 \\
$Y_{r}$ & $\mathrm{kWh} / \mathrm{kWp}$ & 4.27 & 4.32 & 4.22 & 1.78 \\
$L_{c}$ & $\mathrm{kWh} / \mathrm{kWp}$ & 0.27 & 0.41 & 0.64 & -46.88 \\
$L_{s}$ & $\mathrm{kWh} / \mathrm{kWp}$ & 0.08 & 0.15 & 0.21 & -45.24 \\
$P R$ & $\%$ & 91.7 & 87.4 & 79.8 & 12.22 \\
$\eta_{A, \text { rated }}$ & $\%$ & 13.8 & 13.8 & 14.9 & -7.38 \\
$\eta_{A}$ & $\%$ & 13.0 & 12.6 & 12.7 & 0.79 \\
$\eta_{f}$ & $\%$ & 12.7 & 12.1 & 11.9 & 4.20 \\
$\eta_{\text {inv }}$ & $\%$ & 97.8 & 96.2 & 94.0 & 3.19 \\
$C F$ & $\%$ & 16.3 & 16.0 & 14.1 & 14.54 \\
\hline
\end{tabular}

The maintenance practices applied to the PV modules and measurement equipment can introduce uncertainties that result in high values of degradation. The measurement equipment in the PV systems in Cirata was not cleaned and calibrated, the CIS PV modules were sometimes cleaned, and the c-Si PV modules were never cleaned during their operation. Soiling and drifting of the irradiance sensors increase the uncertainty of the $R_{d}$ calculation, which is an interesting topic for further investigation.

(a)
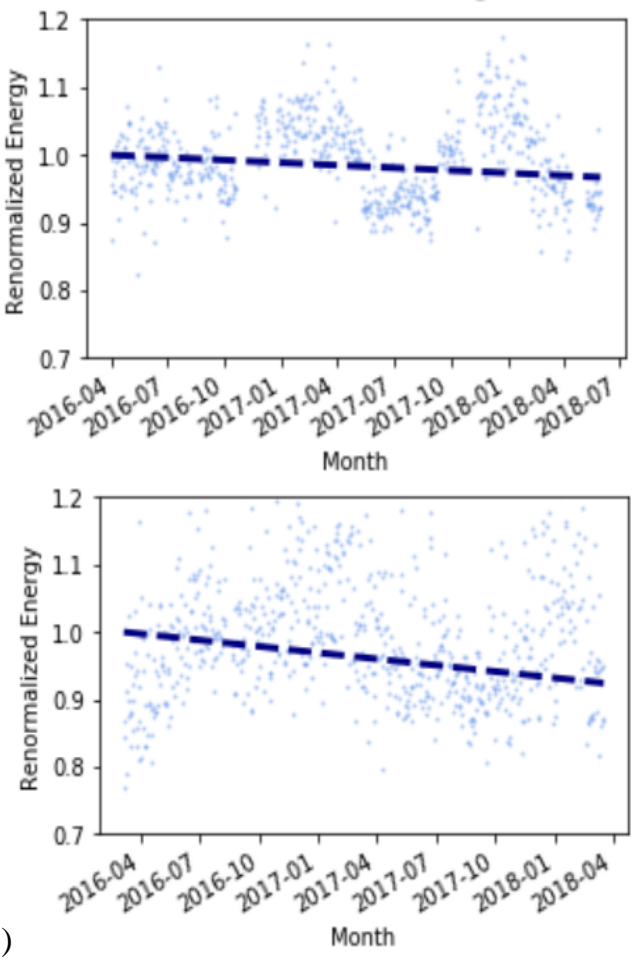
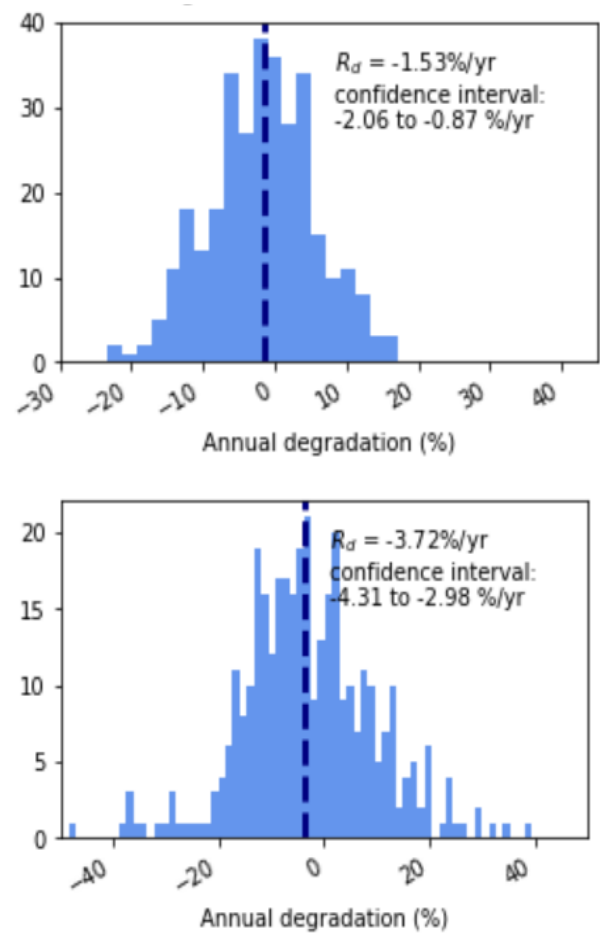

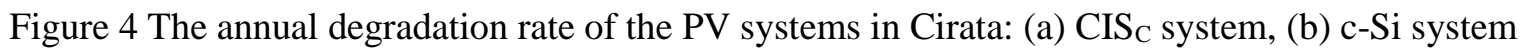


The degradation rates of the PV systems in Cirata at module level were higher than those reported in the literature, where the average degradation rates for silicon and thin-film technology are respectively $0.7 \%$ and $1.5 \%$ per year. However, when looking at the system level, the $R_{d}$ values from Cirata are within the boundaries as presented in other literature (Jordan \& Kurtz, 2013).

For silicon technology, the average rate of degradation at module level is $0.5 \%$ /year. However, it is possible for the rate of system degradation to reach $2.5 \%$ /year. This also indicates that BOS and soiling affect degradation (Jordan \& Kurtz, 2013). For the CIS module, the examination of yields from NREL found that the $R_{d}$ of CIS can range from moderate, at $2 \%$ to $4 \%$ per year, to negligible or small, at less than $1 \% / y e a r$ (Del Cueto et al., 2008).

\section{CONCLUSION}

We compared the performance and degradation rate of a 1 MW CIS PV system and a $5 \mathrm{~kW}$ crystalline-Si PV system operating in the real tropical climate of Indonesia. Concerning the $Y_{f}$, the CIS system outperformed the c-Si system by $14 \%$. The daily-averaged $P R$ of the CIS system was $89.6 \%$ (mean $P R$ of the central and string clusters), which is $12.2 \%$ higher relative to the $P R$ of the c-Si system of $80 \%$.

Based on monitored $P_{a c}$, the $R_{d}$ of the PV systems in Cirata at the module level was high. The CIS system degraded by $1.53 \%$ per year, while the $R_{d}$ of the c-Si system was $3.72 \%$ per year. However, at the system level, the $R_{d}$ values were within acceptable boundaries. By considering the other technical performance indicators, it can be concluded that CIS technology performs better than c-Si in Indonesia's tropical climate. However, there may be some uncertainty with respect to the calculation of the $R_{d}$. Such uncertainties are caused by soling and the relatively short two-year monitoring period.

\section{ACKNOWLEDGEMENT}

We appreciate the financial support from the Indonesia Endowment Fund for Education (LPDP) and the expert support from Advanced Research on Innovations in Sustainability and Energy (ARISE) of the University of Twente. Thanks to COST Action PEARL PV for the Short Term Scientific Mission (STSM) grant at Eurac Research in Bolzano, Italy.

\section{REFERENCES}

Creutzig, F., Agoston, P., Goldschmidt, J.C., Luderer, G., Nemet, G., Pietzcker, R.C., 2017. The Underestimated Potential of Solar Energy to Mitigate Climate Change. Nat. Energy, Volume 2(9), doi:10.1038/nenergy.2017.140

Dasuki, A.S., Djamin, M., Lubis, A.Y., 2001. The Strategy of Photovoltaic Technology Development in Indonesia. Renewable Energy, Volume 22(1-3), pp. 321-326

Del Cueto, J.A., Rummel, S., Kroposki, B., Osterwald, C., Anderberg, A., 2008. Stability of CIS/CIGS Modules at the Outdoor Test Facility Over Two Decades. In: IEEE Photovoltaic Specialist Conference held May 11-16

Elfani, M., 2011. The Impact of Renewable Energy on Employment in Indonesia. International Journal of Technology, Volume 2(1), pp. 47-55

Fraunhofer ISE, 2019. Photovoltaics Report 2019. Freiburg

Hasselbrink, E., Anderson, M., Defreitas, Z., Mikofski, M., Shen, Y.C., Caldwell, S., Terao, A., Kavulak, D., Campeau, Z., Degraaff, D., 2013. Validation of the PVLife Model using 3 Million Module-years of Live Site Data. In: Conference Record of the IEEE Photovoltaic Specialists Conference, Tampa, FL, USA

Honrubia-Escribano, A., Ramirez, F.J., Gómez-Lázaro, E., Garcia-Villaverde, P.M., RuizOrtega, M.J., Parra-Requena, G., 2018. Influence of Solar Technology in the Economic 
Performance of PV Power Plants in Europe. A Comprehensive Analysis. Renewable Sustainable Energy Reviews, Volume 82, pp. 488-501

John, J.J., Alnuaimi, A., Elnosh, A., Stefancich, M., Banda, P., 2018. Estimating Degradation Rates from 27 Different PV Modules Installed in Desert Conditions using the NREL/Rdtools. In: 2018 IEEE $7^{\text {th }}$ World Conference on Photovoltaic Energy Conversion, WCPEC 2018 - A Joint Conference of $45^{\text {th }}$ IEEE PVSC, $28^{\text {th }}$ PVSEC and $34^{\text {th }}$ EU PVSEC, USA

Jordan, D.C., Deceglie, M.G., Kurtz, S.R., 2017. PV Degradation Methodology Comparison A Basis for a Standard. In: IEEE $44^{\text {th }}$ Photovoltaic Specialists Conference (PVSC), USA

Jordan, D.C., Deline, C., Kurtz, S.R., Kimball, G.M., Anderson, M., 2018. Robust PV Degradation Methodology and Application. IEEE Journal of Photovoltaics, Volume 8(2), pp. 525-531

Jordan, D.C., Kurtz, S.R., 2013. Photovoltaic Degradation Rates - An Analytical Review. Progress in Photovoltaics Research and Applications, Volume 21, pp. 12-29

Kunaifi, K., Reinders, A.H.M.E., 2017. Estimating the Technical Potential of Grid-connected PV Systems in Indonesia: A Comparison of a Method based on Open Access Data with a Method based on GIS. In: $33^{\text {rd }}$ European Photovoltaic Solar Energy Conference and Exhibition. WIP Renewable Energies, Amsterdam, pp. 2652-2658

Kunaifi, K., Reinders, A.H.M.E., 2018. Performance of a Remote Hybrid PV System based on Real and Modelled Data in Indonesia. In: The $35^{\text {th }}$ European Photovoltaic Solar Energy Conference and Exhibition (EU-PVSEC), At Brussels, Belgium, pp. 2060-2065

Kunaifi, Reinders, A., 2018. Perceived and Reported Reliability of the Electricity Supply at Three Urban Locations in Indonesia. Energies, Volume 11(1), pp. 1-24

Meyer, E.L., van Dyk, E.E., 2004. Assessing the Reliability and Degradation of Photovoltaic Module Performance Parameters. IEEE Transactions on Reliability, Volume 53(1), pp. 83-92 Ministry of Energy and Mineral Resources, 2012. Solar Energy in Indonesia: Potentials, Plannings and Framework Conditions. Berlin

Nazir, R., Nurdin, M., Fitrianto, E., 2016. Voltage Profile Improvement of the $20 \mathrm{kV}$ Painan Distribution System with Multiple Distributed Renewable Energy Generation. International Journal of Technology, Volume 7(1), pp. 26-37

NREL, 2018. RdTools version 1.2.2

PJB, 2019. PJB Unit Pembangkitan. Available Online at https://www.ptpjb.com/unitpembangkitan/, Accessed on May 29, 2019

PLN, 2018. Statistik PLN 2017. Perusahaan Listrik Negara (PLN), Jakarta, Indonesia

Pryor, T., Watt, M., Watt, M., 2013. Australian Technical Guidelines for Monitoring and Analysing Photovoltaic Systems Version 1. Australian PV Institute

Reinders, A., Sudradjat, A., Dijk, V. Van, Mulyadi, R., Turkenburg, W., 1999. Sukatani Revisited: On the Performance of Nine-year-old Solar Home Systems and Street Lighting Systems in Indonesia. Renewable Sustainable Energy Reviews, Volume 3(1), pp. 1-47

Setiawan, A., Setiawan, E.A., 2017. Optimization of a Photovoltaic Power Plant in Indonesia with Proper Tilt Angle and Photovoltaic Type using a System Advisor Model. International Journal of Technology, Volume 8, pp. 539-548

The International Electrotechnical Commission, 2017. IEC 61724-1 Photovoltaic System Performance - Part 1: Monitoring

Veldhuis, A.J., Reinders, A.H.M.E., 2015. Reviewing the Potential and Cost-effectiveness of Off-grid PV Systems in Indonesia on a Provincial Level. Renewable Sustainable Energy Reviews, Volume 52, pp. 757-769 